\title{
A preboreal elk (Alces alces L., 1758) antler from south-eastern Norway
}

Finn Audun Grondahl, Anne Karin Hufthammer, Svein Olaf Dahl and Jorgen Rosvold

\author{
Grøndahl FA, Hufthammer AK, Dahl SO and Rosvold J. 2010. A Preboreal elk antler from south- \\ eastern Norway. Fauna norvegica 30: 9-12.
}

\begin{abstract}
In 1895 a shed elk antler was found in a mire on a farm near Fluberg, in Søndre Land municipality in south-eastern Norway. The antler was first radiocarbon dated in 2008 and yielded the age 9,100 \pm 50 BP $(8,340-8,250$ BC), which is the oldest dated elk remain from Norway. Elk (Alces alces L., 1758) are a pioneer colonising species; they were already established south of the ice front in Denmark and southern Sweden in the Late Glacial period.

This antler shows that the species had arrived in south-eastern Norway in the late Preboreal period. This could tie in with the earliest arrival of elk once the colonizing routes from southern Sweden were established 9,300-9,200 BP. The antler is clearly of the palmate morph, and strongly resembles elk antlers found in Denmark and southern Sweden from the Late Glacial and Early Holocene periods. This find also reveals that the vegetation at the end of the Preboreal period suited large herbivores such as elk.
\end{abstract}

Keywords: Alces alces, elk, preboreal, immigration, antler morphology, south-eastern Norway

doi: 10.5324/fn.v30i0.629. Recieved: 2010-03-09. Accepted: 2010-07-02. Published online: 2010-12-21.

Finn Audun Grøndahl, Randsfjordmuseene AS, Kongeveien 92, NO-2770 Jaren

Anne Karin Hufthammer, University of Bergen, Natural History Collections, PO Box 7800, NO-5020

Bergen

Svein Olaf Dahl, Department of Geography, University of Bergen, PO Box 7800, NO-5020 Bergen

Jørgen Rosvold, Norwegian University of Science and Technology, Museum of Natural History and Archaeology, NO-7491 Trondheim

Corresponding author: Finn Audun Grøndahl

E-mail:fag@randsfjordmuseene.no

Phone: +4790587789.

\section{INTRODUCTION}

Sub-fossil remains of vertebrates, in particular bones, have been found in large parts of Norway. Isolated finds are however rare, and most derive from archaeological excavations of human dwelling sites. Such finds are primary evidence for faunal immigration history, and may provide important information about how the landscape and vegetation have developed.

Little is known about Norwegian vertebrate fauna during the Preboreal, the first millennia of the Holocene. Elk (Alces alces L., 1758) were however one of the first new mammal species to migrate into Norway as the ice receded. A shed antler found in a drained bog in Hov in Løten municipality, Hedmark county, was ${ }^{14} \mathrm{C}$-dated to $8,520 \pm 140 \mathrm{BP}$ (Henningsmoen 1975), and has until now been the oldest dated find of the species. Burnt bones of elk together with beaver (Castor fiber L., 1758) and wild boar (Sus scrofa L., 1758) have also been found in a coastal human dwelling site at Tørkop, in Halden municipality in Østfold county. This site has been ${ }^{14} \mathrm{C}$ dated by charcoal to between 8,800 and 7,000 BP (Mikkelsen et al. 1999; Hufthammer 2006).

In this article we report a new ${ }^{14} \mathrm{C}$ dating of an isolated find of an elk antler, pushing back its arrival to Norway by several hundred years. We provide a description of its morphological characteristics, and discuss the ecological implications of the find. 


\section{MATERIAL AND METHODS}

The antler was found in 1895 by workers digging a ditch in a bog near Fluberg (UTM 32 north 6738500 east 570300) 420 m.a.s.l. in Søndre Land municipality in Oppland county (Figure 1), and the find has been kept on the farm ever since. It was located at a depth of about $1 \mathrm{~m}$, but the exact find site is unknown. The find was briefly described by Collett (1912) who indicated that

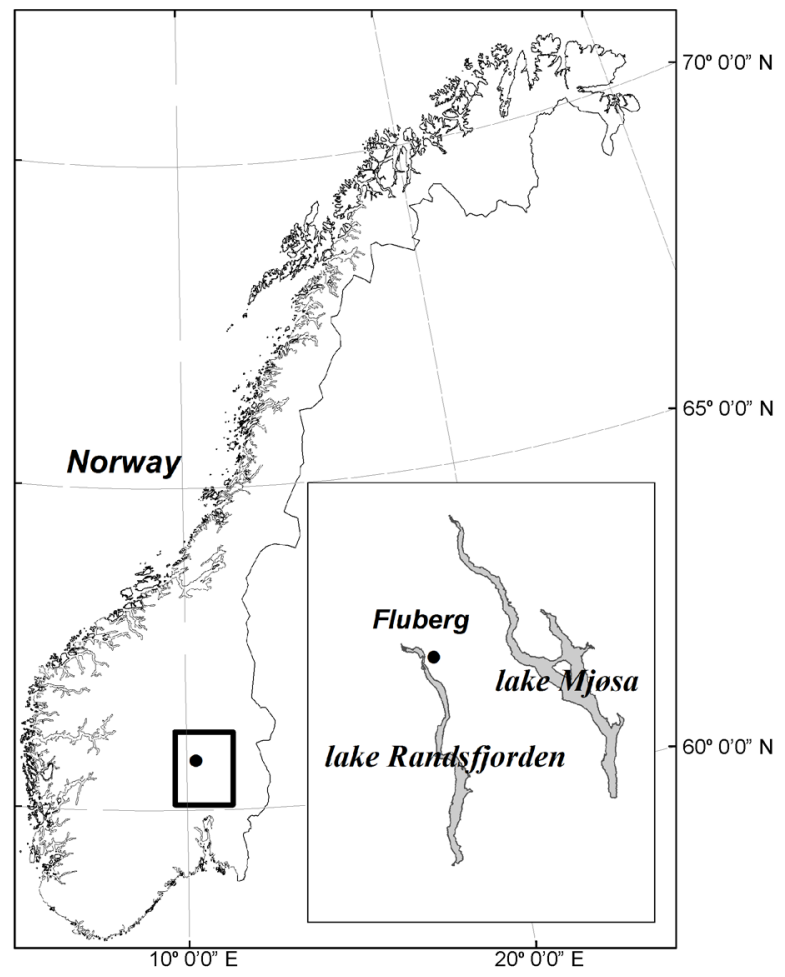

Figure I. The map shows the site of the antler find north-east of the lake Randsfjorden (C Norge digitalt). it might be of Late Glacial age. A 1.4 gram section of the antler by the pedicle was sent for ${ }^{14} \mathrm{C}$ dating by accelerator mass spectrometry (AMS) at the Poznan Radiocarbon Laboratory in Poland. The ${ }^{14} \mathrm{C}$ date was calibrated using CALIB 5.0.1 (Stuiver $\&$ Reimer 1993) with the calibration curve Intcal04 (Reimer et al. 2004), using 1 standard deviation ranges. If not specified, all the reported ages are in ${ }^{14} \mathrm{C}$ years before present $(\mathrm{BP})$.

\section{RESULTS}

The elk antler from Fluberg has been dated to $9,100 \pm 50 \mathrm{BP}$ (Poz-22238) which corresponds to 8,340-8,250 BC. This is the oldest dated elk remain from Norway.

The antler, which has been shed, is clearly of the palmate morph with 13 tines and no apparent form of division (Figure 2). All the tines are short, measuring between $5-175 \mathrm{~mm}$, with two being so small that they are barely measurable. The length of the beam is unknown as it had been sawn off upon mounting. The antler has been evaluated according to the C.I.C. standard, and was awarded 283 points, which meets the requirement for a silver medal. Morphologically the antler shows strong resemblance to antlers found in southern Sweden and Denmark from the Late Glacial and Early Holocene periods (Liljeborg 1874; Liljegren \& Lagerås 1993; Aaris-Sørensen 2009).

\section{DISCUSSION}

Reindeer (Rangifer tarandus L., 1758), polar bear (Ursus maritimus Phipps, 1774) and stoat (Mustela erminea L., 1758) are known from the Late Glacial period in Norway (Fjellberg 1978; Blystad et al. 1983; Lie 1986; Hufthammer 2001). The elk antler from Fluberg is the oldest Holocene find of a terrestrial mammal in Norway, with the exception of a reindeer
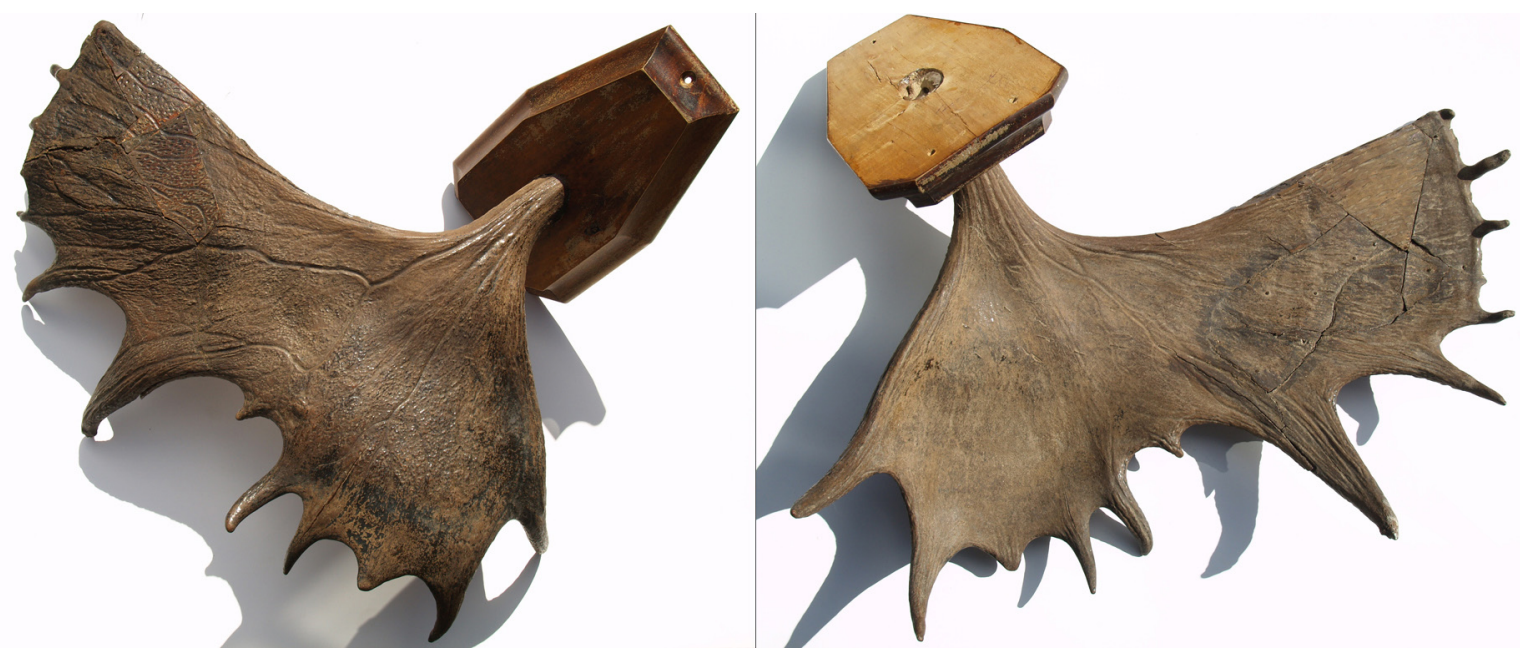

Figure 2. The elk antler from Fluberg, Søndre Land municipality in south-eastern Norway. Photo: Finn Audun Grøndahl. 
antler from Egersund in Rogaland county that has been dated to $10,255 \pm 80 \mathrm{BP}$ (T-8821) (Osteological Archive, Natural History Collections, University of Bergen). The Fluberg antler is also one of the very few mammal remains from inland southeastern Norway. The shed antler is almost intact, which is rare as almost all prehistoric Holocene bone finds from eastern Norway are small burnt fragments (Hufthammer 2006). The find confirms the elk as a pioneer species in Norway.

At the start of the Holocene most of the Scandinavian peninsula was covered by ice (Andersen \& Borns 1997). Southern Sweden however was free of ice before 14,000 BP (Lagerlund \& Houmark-Nielsen 1993), and elk bones from this area have been dated to about 11,345 $\pm 70 \mathrm{BP}$ (LuS-7685) (Aaris-Sørensen 2009). Until about 9,300-9,200 BP southern Sweden was separated from the rest of the peninsula by the Närke Strait (Björck, fig 14, 1995). The northward immigration of mammals probably occurred as soon as colonizing routes were established. The Fluberg antler thus shows that elk were among the first mammals to colonize south-eastern Norway. This is not surprising since elk, and especially young bulls, have a strong dispersal propensity. Young bulls have been recorded dispersing several hundred km (Hoffman et al. 2006). They are able to move through alpine areas, over ice covered lakes, and have no problems with crossing open waters (Collett 1912). Elk are also adapted to exploit vegetation in early stages of succession where willows (Salix spp.), birch (Betula spp.) and Scots pine (Pinus sylvestris) are important browse (Andersen \& Sæther 1996).

The Fluberg antler is very large compared to the average size of those of modern Norwegian elk (Solberg et al. 2006). Elk remains from Late Pleistocene and Early Holocene times in Europe suggest that the species had a larger body and considerably larger antlers than modern elk (Kurtén 1968). The landscape south of the glaciers at the end of the Last Ice Age was characterized by open steppe tundra vegetation (Andersen 2000), and antler mass of ungulates is generally larger in open as opposed to forest landscapes (Geist 1999). The frequency of palmate antlers increase to the north and with increasing body size (Sæther \& Haagenrud 1985; Engan 2001). The largest antlers are in general found among six year olds which, in modern Norwegian populations, have an average of 10-12 antler tines in total (Solberg et al. 2006). The antler therefore represents a prime-aged bull in very good condition.

\section{The ecological context}

At the beginning of the Holocene the ice sheet extended to the Oslo area (Andersen 1980). During the following centuries a dramatic climate improvement caused the rapid withdrawal of the ice from large parts of eastern Norway, and at about 9,000 BP the ice margins in south-eastern Norway were situated just north of the find (Sørensen 1983).

The Fluberg antler shows that the area was ice free, and that the vegetation was able to sustain elk. Pollen analytical examinations have been done in several sites not far from Fluberg (Figure 3). A pollen sample from the lowest layer in a bog (9,000-8,700 BP), in Østsinni in Nordre Land municipality, 545 m.a.s.l. and $9 \mathrm{~km}$ north of Fluberg, shows that pioneer species such as sea-buckthorn (Hippóphaë rhamnoides L., 1758), dwarf birch (Betula nana L., 1758), willow (Salix spp.) and birch (Betula spp.) dominated (Høeg 1990). The lowest layers of the Skonnord bog (9,100-8,100 BP) in Gjøvik municipality, 436 m.a.s.l. and $15 \mathrm{~km}$ east of Fluberg, show the same type of vegetation with the addition of juniper (Juniperus communis L., 1758) (Høeg 2007). This is further confirmed by a pollen diagram from a bog near Engelaug in Løten municipality, 184 m.a.s.l. and $60 \mathrm{~km}$ east of Fluberg, where a pioneer shrub vegetation dominated in the lowest layer (9,700-9,350 BP) followed by open birch forest (9,350-9,050 BP) (Høeg 1996).

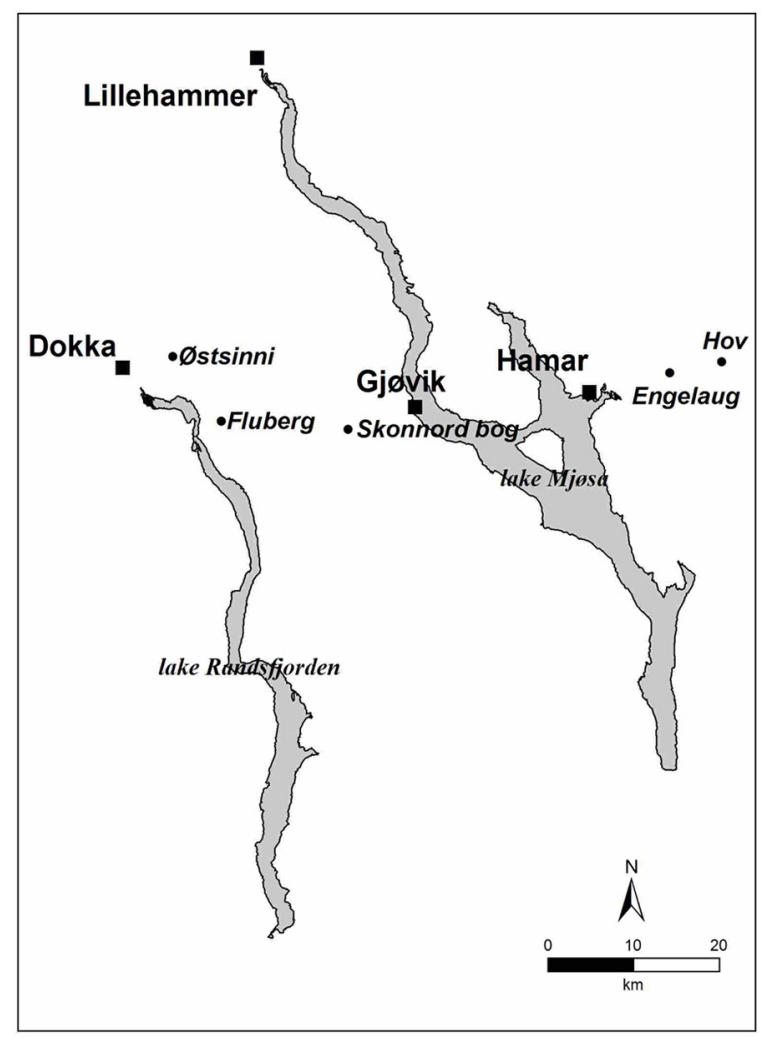

Figure 3. The map shows pollen analytical examination sites close to the find site of the Fluberg antler. Hov is the find site of the elk antler from Løten municipality, Hedmark county (C) Norge digitalt). 


\section{CONCLUSIONS}

The Fluberg antler confirms the elk as a pioneer species in the inland of south-eastern Norway at the end of the Preboreal. Elk colonized southern Norway as soon as it was physically possible, and when the area could provide sufficient browse for the species. The antler shows a prime-aged bull in very good condition.

\section{ACKNOWLEDGEMENTS}

The Fretheim family in Fluberg has been very helpful, and allowed samples to be taken from the antler for dating. Geir Høitomt gave useful assistance. Kim Aaris-Sørensen, Thijs van Kolfschoten, Helge Irgens Høeg, Mona Henriksen, Reidar Andersen and Vidar Holthe read the manuscript and supplied with important information. Ola Hellerud must be specially thanked for the maps he produced. Alastair Brown assisted with the English translation.

\section{REFERENCES}

Aaris-Sørensen K. 2009. Diversity and dynamics of the mammalian fauna in Denmark throughout the last glacial-interglacial cycle, 115-0 kyr BP. Fossils and Strata 57. 59p.

Andersen BG. 1980. The deglaciation of Norway after 10,000 B.P. Boreas 9: 211-216.

Andersen BG. 2000. Istider i Norge. Landskap formet av istidens breer. Oslo. Universitetsforlaget.

Andersen BG, Borns HW. 1997. The ice age world. Oslo. Scandinavian University Press.

Andersen R, Sæther BE. 1996. Elg i Norge. Biologi, atferd og forvaltning. Oslo. Teknologisk forlag.

Björck S. 1995. A review of the history of the Baltic Sea, 13.0-8.0 ka BP. Quaternary International 27:19-40.

Blystad P, Thomsen H, Simonsen A, Lie RW. 1983. Find of a nearly complete Late Weichelian polar bear skeleton, Ursus maritimus Phillips, at Finnøy, southwestern Norway: a preliminary report. Norsk Geologisk Tidsskrift 2-3: 193-197.

Collett R. 1912. Norges pattedyr. Kristiania. Aschehoug.

Engan JH. 2001. Changes in the relationship between palmate and cervine antlers in moose (Alces alces) in southeastern Norway. Alces 37(1): 79-88.

Fjellberg A. 1978. Fragments of a Middle Weichelian fauna on Andøya, north Norway. Boreas 7: 39.

Geist V. 1999. Deer of the World. Their Evolution, Behaviour and Ecology. Swan Hill Press

Henningsmoen KE. 1975. Elghornet fra Hov i Løten. Årbok for Norsk skogbruksmuseum 7: 62-73.

Hoffman JD, Genoways HH, Choate JR. 2006. Long-distance dispersal and population trends of moose in the central United States. Alces 42: 115-131.
Hufthammer AK. 2001. The Weichelian (c. 115,000 - 10, 000 B.P.) vertebrate fauna of Norway. Bollettino della Società Paleontologica Italiana 40 (2): 201-208.

Hufthammer AK. 2006. The vertebrate fauna of eastern Norway - from the Ice Age to the Middle Ages. Skrifter (Kulturhistorisk Museum, Universitetet i Oslo) 4: 191-202.

Høeg HI. 1990. Den pollenanalytiske undersøkelsen ved Dokkfløyvatn i Gausdal og Nordre Land, Oppland. Varia, Oslo 21: 1-145.

Høeg HI. 1996. Pollenanalytiskeundersøkelseri “Østerdalsområdet" med hovedvekt på Rødsmoen, Åmot i Hedmark. Varia, Oslo 39: 1-163.

Høeg HI. 2007. Pollenanalytiske undersøkelser i Snertingdal. Varia, Oslo 62: 173-187.

Kurtén B. 1968. Pleistocene mammals of Europe. London. Weidenfeld and Nicolson.

Lagerlund E, Houmark-Nielsen M. 1993. Timing and pattern of the last deglaciation in the Kattegat region, southwest Scandinavia. Boreas 22(4): 337-347.

Lie RW. 1986. Animal bones from the Late Weichslian in Norway. Fauna Norvegica Ser. A: 41-46.

Liljeborg W. 1874. Sveriges og Norges Ryggradsdjur. I. Däggdjuren. Upsala, W. Schultz:819-820

Liljegren R, Lagerås P. 1993. Från mammutstäpp til kohage. Djurens historia i Sverige. Wallin \& Dalholm Boktr. AB, Lund. $48 \mathrm{p}$

Liljegren R, Ekström J. 1996. The terrestrial late glacial fauna in South Sweden. Acta Archaeologica Lundensia. Series in 80 24: 135-139.

Mikkelsen E, Ballin TB, Hufthammer AK. 1999. Tørkop. A Boreal Settlement in South-Eastern Norway. Acta Archaeologica 70: 25-57.

Reimer PJ, Baillie MGL, Bard E, Bayliss A, Beck JW, Bertrand CJH, Blackwell PG, Buck CE, Burr GS, Cutler KB, Damon PE, Edwards RL, Fairbanks RG, Friedrich M, Guilderson TP, Hogg AG, Hughen KA, Kromer B, McCormac G, Manning S, Ramsey CB, Reimer RW, Remmele S, Southon JR, Stuiver M, Talamo S, Taylor FW, van der Plicht J, Weyhenmeyer CE. 2004. IntCal04 terrestrial radiocarbon age calibration, 0-26 cal kyr BP. Radiocarbon 46(3): 1029-1058.

Sæther BE, Haagenrud H. 1985. Geographical variation in the antlers of Norwegian moose in relation to age and size. J. Wildl. Manage. 49(4): 983-986.

Solberg EJ, Rolandsen CM, Heim M, Grøtan V, Garel M, Sæther B-E, Nilsen EB, Austrheim G, Herfindal I. 2006. Elgen i Norge sett med jegerøyne. En analyse av jaktmaterialet fra overvåkningsprogrammet for elg og det samlede sett elg-materialet for perioden 1966-2004. NINA Rapport 125.

Stuiver M, Reimer PJ. 1993. Extended C-14 data-base and revised CALIB 3.0 C-14 age calibration program. Radiocarbon 35(1): 215-230.

Sørensen R. 1983. Glacial deposits in the Oslofjord area. In: Ehlers, J. (ed.): Glacial deposits in North-West Europe, 19-28. A.A. Balkema, Rotterdam 